\title{
The Role of International Factors and International Market in a Turbulent Company Environment
}

\author{
Tetiana Mostenska ${ }^{\star}$, Oksana Piankova ${ }^{\dagger}$ and \\ Oleksandra Ralko \\ ${ }^{*} \mathrm{PhD}$, Professor, National University of Life and \\ Environmental Sciences of Ukraine \\ ${ }^{\dagger} \mathrm{PhD}$, Associate Professor, Kyiv National Trade and Economics University \\ ${ }^{*}$ PhD, Associate Professor, National University of Life and \\ Environmental Sciences of Ukraine
}

\section{Introduction}

Carrying out a study of pro-ecological restructuring at Ukrainian enterprises, the authors came to the conclusion that these processes are in the development stage by both qualitative and quantitative criteria. At the level of top management, pro-ecological changes are not a priority. In Ukraine, historically (due to the fact that Ukraine was part of the USSR) entrepreneurs' attitudes show some disregard to the value of resources, both natural and labour, and therefore the main incentives for changes at the macro and micro levels are precisely external factors. Thus, various laws and development programs are being adopted at the state level, sustainable development strategies are being developed, but they are mostly declarative in nature. The main motivation for changes at the state level at the moment are commitments to the IMF, EBRD, the EU and deterioration of relations with Russia. The last one is mainly displayed in energyintensive industries and is associated with an increase in prices for gas and other fuel resources. At the enterprise level, any changes that can be attributed

\section{How to cite this book chapter:}

Mostenska, T., Piankova, O. and Ralko, O. 2019. The Role of International Factors and International Market in a Turbulent Company Environment. In: Gąsior, A. (ed.) Pro-ecological Restructuring of Companies: Case Studies, Pp. 15-44. London: Ubiquity Press. DOI: https://doi.org/10.5334/bbk.c. License: CC-BY 4.0 
to pro-ecological mainly occur due to economic feasibility. Fuel costs have been raised for the enterprises, and so to reduce the cost of production in view of the low purchasing capacity of the population, they implement energy-saving technologies. Another motive for carrying out pro-ecological processes is the enterprise's entrance to foreign markets. All other factors - environmental, social and cultural - have no impact on pro-ecological restructuring. At a business forum that was held in Kiev in November 2017 that was devoted to issues of inclusive and sustainable development, business representatives voiced a simple idea that can be reduced to the following: as long as fines for harm to the environment are minimal, no one will introduce technology that will reduce this harm. The issues of the same corporate social responsibility are mainly dealt with by companies whose products causes the most harm to the population, namely the tobacco and alcohol industry.

In general, if we consider the degree of development of corporate social responsibility towards issues of ecology and energy conservation, it is very low. If we consider the prevalence of pro-ecological restructuring processes in all sectors of Ukraine, it should be noted that in the past few years, due to strained relations with Russia, the rise in fuel costs and gas supply disruptions, most of the enterprises were forced to introduce energy-saving technologies.

The sectoral structure of Ukraine over the last 10 years has been characterized by the high proportion of agro-industrial products. So both in the structure of the domestic market and in Ukraine's exports, agricultural and food production occupies about $35 \%$. It is the export orientation of these sectors that determined the most dynamic pro-ecological processes in enterprises that were forced to adapt to the demands of foreign markets. Therefore, the authors selected the agricultural and food industries as a vivid example of pro-ecological restructuring. From the agricultural and food industries, we selected the market for eggs and egg products as the most developed and export-oriented.

In conditions of worsening of food security problems and environmental challenges in food production, the issues of ensuring humanity in quality and inexpensive food are particularly relevant. Eggs and egg products belong, in particular, to the category of quality and inexpensive food products.

The international market of eggs belongs to growing markets, due to the fact that eggs are one of the cheapest products. "Eggs are a superfood that can help alleviate malnourishment and protein poverty" (Davies 2018). The volume of production and consumption of raw eggs in most countries covers the domestic market, due to shorter product shelf life. At the same time, export of dry egg products has grown. However, the egg market is very vulnerable due to the significant influence of external environmental factors.

Except public consumption of eggs (eggs are the cheapest source of animal protein), the largest consumers of egg products are enterprises of the confectionery and oil fat industry, as for them eggs are raw materials. Egg product consumers are also bakeries, the meat processing industries and HoReCa (hotels, bars, cafés and restaurants). 
Growth in the food industry will stimulate additional demand for both dry and liquid egg products. Given the annual increase in the production of eggs and egg products, and expansion of markets of their use, both markets will certainly grow. Egg product manufacturers will strengthen their market positions by improving production technology, increasing production volume, expanding the range of egg products, finding new ways of marketing, increasing exports and so on. With the growth of the production the issues of ecologization of eggs and egg products has become particularly relevant.

AVANGARDCO IPL is one of the largest agro-industrial companies in Ukraine, specializing in the production of eggs and egg products. To maintain and extend its positions both in domestic and foreign markets, the company implements measures to reduce production costs and enhance product quality control.

\section{The Objective and Methodology}

People around the globe need a safe, plentiful and inexpensive food supply, to provide a balanced diet, essential for sustained human health. Producers of eggs and egg products help to solve the food problem by providing population with animal proteins. On the efficiency of eggs and egg products producers influence the following international environment factors: currency fluctuations, supply and demand, prices etc.

The purpose of writing the case study is to determine the international factors and the requirements of the international market that affect the activities of the vertically integrated company AVANGARDCO IPL, as well as determining the impact of production ecologization on the effectiveness of the company.

Reorientation of different enterprises on low-waste cycles is based on implementing innovative cleaning and abatement equipment, ecologization of technological processes. Environmentally safe production should become the leading branch, expand the scope of employment and bring considerable profit. Environmental regulations must not conflict with economic interests when the deterioration of the environment is less profitable than the solution to environmental problems.

The subject of the research is methodological and practical approaches to determining the impact of external environmental factors on company activity and the ability to adapt the company's strategy to external exciters by enhancing flexibility and making effective management decisions.

The object of the research is process of influence of international factors on the internal environment of AVANGARDCO IPL with the aim of developing mechanisms to neutralize the negative effects of changes in the external environment and increased production volumes. Such an approach allows us to define the priority areas for decision-making in the field of environmental control processes of the company. 
The state of international and national markets of eggs and egg products is analyzed using statistical materials from the World Egg Organization (www. internationalegg.com), the Ministry of agrarian policy and food of Ukraine (www.minagro.gov.ua) and State Statistics Service of Ukraine (www.ukrstat. gov.ua). Analysis and characterization of AVANGARDCO IPL was conducted on the basis of the official website of the company (www.avangardco.ua/en/). Analysis and characterization of the biggest competitor of AVANGARDCO IPL - the company Ovostar - was conducted on the basis of the official website of the company (www.ovostar.ua/en/).

\section{Short History and Performance of the Company}

The Ukrainian company AVANGARDCO IPL ranks second among the world leaders in egg producers by the number of laying hens in production 27 million hens - and ranks first as producer of eggs and dry egg products in Ukraine and first in Eurasia.

AVANGARDCO IPL's major activities include:

- Breeding of industrial laying hens, production and sales of shell eggs.

- Production and sales of dry egg products.

- Incubation and sales of one-day-old laying hens, breeding and sales of young laying hens and sales of poultry for slaughter.

- Production and sales of feed.

- Other activities include sales of goods and services, poultry meat and byproducts, organic fertilizer etc.

AVANGARDCO IPL consists of 19 laying farms, 10 rearing farms, six feed mills, three hatcheries, two poultry complexes, Avis and Chornobaivske, and the egg processing plant Imperovo Foods. Production facilities in 14 regions of Ukraine allow the company to meet the demand of Ukrainian consumers in an efficient and timely manner.

The main stages of the company development are summarized in Table 1.

In 2015, Avangardco IPL added seven new countries to its already impressive portfolio of 42 country markets by starting to export its shell eggs to Qatar and Israel and its egg products to the UK, Bangladesh, Iran, Latvia and Italy. However, the deterioration in the market, accompanied by reduction in the consumption of eggs was the reason that the volume of shell eggs in 2015 decreased by $46 \%$, while their sales fell by $35 \%$, accompanied by a decrease in company revenue by $43 \%$. Main company performances are in Table 2. Gross profit from production of shell eggs decreased by $84 \%$ to 14,636 thousand USD. In 2015 there was also a decrease of gross profit margin to $9 \%$.

Production of dry eggs also decreased. If in 2014 83\% of dry eggs were marketed outside Ukraine, then in 2015 the share of exports dropped to $78 \%$ 
Table 1: Main stages of the AVANGARDCO IPL development.

\begin{tabular}{|l|l|}
\hline \multicolumn{1}{|c|}{ Year } & \multicolumn{1}{c|}{ Event } \\
\hline 2003 & $\begin{array}{l}\text { Purchase of the Avangardco poultry farm located in West Ukraine not } \\
\text { far from Ivano-Frankivsk }\end{array}$ \\
\hline $2003-2009$ & $\begin{array}{l}\text { The company purchased additional 18 laying farms, three hatcheries, } \\
\text { three rearing farms and four feed mills. }\end{array}$ \\
\hline 2009 & The company commissioned a modern egg processing plant. \\
\hline 2010 & $\begin{array}{l}\text { Avangardco IPL made itself known on the international financial } \\
\text { markets by successfully completing an IPO on the London Stock } \\
\text { Exchange and attracting 208 million USD in investment. An additional } \\
\text { 200 million USD was raised through a Eurobond placement. }\end{array}$ \\
\hline $2011-2013$ & $\begin{array}{l}\text { The company modernized poultry complexes, laying capacity } \\
\text { increased to 30.1 million hens, while annual production capacity } \\
\text { reached 8.6 billion eggs. }\end{array}$ \\
\hline $\begin{array}{l}\text { Imperovo Foods received official authorization to export dry egg } \\
\text { products to the European Union. } \\
\text { The company's eggs and dry egg products became Kosher certified. }\end{array}$ \\
\hline 2015 & $\begin{array}{l}\text { The company added seven new country markets to its export } \\
\text { destinations for a total of 42. The share of the EU in egg powder } \\
\text { exports rose to 40\%. }\end{array}$ \\
\hline $\begin{array}{l}\text { The company successfully restructured a 200 million USD Eurobond } \\
\text { that represents a lion's share of the company debt portfolio. }\end{array}$ \\
\hline
\end{tabular}

Source: AVANGARDCO IPL. Available at: http://www.avangardco.ua/en/.

Table 2: Company effectiveness in shell and dry egg production.

\begin{tabular}{|l|r|r|r|r|r|r|}
\hline \multirow{2}{*}{ Performances } & \multicolumn{3}{c|}{$\begin{array}{c}\text { Production of shell eggs, } \\
\text { billion eggs }\end{array}$} & \multicolumn{4}{c|}{$\begin{array}{c}\text { Production of } \\
\text { dry eggs, tons }\end{array}$} \\
\cline { 2 - 8 } & $\mathbf{2 0 1 4}$ & $\mathbf{2 0 1 5}$ & \multicolumn{1}{c}{$\%$} & $\mathbf{2 0 1 4}$ & $\mathbf{2 0 1 5}$ & $\%$ \\
\hline Production & 6,306 & 3,434 & -46 & 21,323 & 9,057 & -58 \\
\hline Sales & 4,288 & 2,798 & -35 & 185,592 & 11,445 & -38 \\
\hline Revenue, thousand USD & 275,585 & 155,789 & -43 & 116,993 & 64,735 & -45 \\
\hline Exports, \% of sales & 21 & 24 & - & 84 & 89 & - \\
\hline Revenue, \% of total sales & 66 & 68 & - & 28 & 28 & - \\
\hline Gross profit, thousand USD & 89,698 & 14,636 & -84 & 40,365 & 11,805 & -71 \\
\hline Gross profit margin, \% & 33 & 9 & - & 35 & 18 & \\
\hline
\end{tabular}

Source: Avangardco, 2015. Available at: http://avangardco.ua/fileadmin/files/INVESTOR_ RELATIONS/Avangardco_IPL_Annual_Report_2015_final.pdf. 
Table 3: Shell egg sales by channel, \% of volume.

\begin{tabular}{|l|r|r|}
\hline \multirow{2}{*}{\multicolumn{1}{|c|}{ Channels }} & \multicolumn{2}{|c|}{ Years } \\
\cline { 2 - 4 } & $\mathbf{2 0 1 4}$ & $\mathbf{2 0 1 5}$ \\
\hline Retail chains & 35 & 44 \\
\hline Wholesalers & 52 & 41 \\
\hline Exports & 13 & 15 \\
\hline
\end{tabular}

Source: Avangardco, 2015. Available at: http://avangardco.ua/fileadmin/files/INVESTOR_ RELATIONS/Avangardco_IPL_Annual_Report_2015_final.pdf.

(by $5 \%$ ). While revenue of total sales remained unchanged (28\%), gross profit decreased by $71 \%$, which was the reason for the reduction of the gross profit margin to $18 \%$ in 2015 . The company uses one- and two-tier distribution channels: retail chains and wholesalers (Table 3).

In the studied period, there was a change in the structure of the distribution channels of AVANGARDCO. Thus, shell egg sales by retailers increased by $9 \%$ while sales through wholesale traders were reduced by $11 \%$. In addition, during the year, exports grew by $2 \%$.

\section{Role of international factors and international market in a turbulent company environment}

In order to determine the impact of international factors and changes at international markets on AVANGARDCO activity, let's analyze international and Ukrainian markets of eggs and egg products.

\section{The world market of eggs and egg products, key regional markets - importers}

The traditional world leader in production of eggs, since 1990, has been China; after the collapse of the Soviet Union the United States occupied the second place and India and Japan are competing for the third place. In 2000 Ukraine did not belong to the 15 world leader countries in the production of eggs, but in 2010-2013 Ukraine has ranked ninth (Table 4). There is a correlation between large amounts of egg production and the population of the country: eight world leaders are the countries with the biggest population.

In 2015 the geographical structure of production remains unchanged. The leading position in terms of egg production was occupied by China, its share exceeded the nearest competitor - the United States - by four times, and India was in the third place. 
Table 4: World leaders in egg production.

\begin{tabular}{|l|l|l|l|l|}
\hline Place & \multicolumn{1}{|c|}{$\mathbf{1 9 9 0}$} & \multicolumn{1}{c|}{$\mathbf{2 0 0 0}$} & \multicolumn{1}{c|}{$\mathbf{2 0 1 3}$} \\
\hline 1 & China & China & China & China \\
\hline 2 & Soviet Union & The United States & The United States & The United States \\
\hline 3 & The United States & Japan & India & India \\
\hline 4 & Japan & India & Japan & Mexico \\
\hline 5 & Brazil & Russia & Mexico & Japan \\
\hline 6 & India & Mexico & Russia & Russia \\
\hline 7 & Mexico & Brazil & Indonesia & Brazil \\
\hline 8 & Germany & France & France & Indonesia \\
\hline 9 & France & Germany & Ukraine & Ukraine \\
\hline 10 & Spain & Turkey & Turkey & Turkey \\
\hline 11 & Italy & Italy & Spain & Germany \\
\hline 12 & Netherlands & Netherlands & Iran & France \\
\hline 13 & Great Britain & Spain & Italy & Iran \\
\hline 14 & Thailand & Indonesia & Germany & Spain \\
\hline 15 & Poland & Iran & Netherlands & Italy \\
\hline
\end{tabular}

Source: summarized by authors on materials of the journal "Poultry and poultry products".

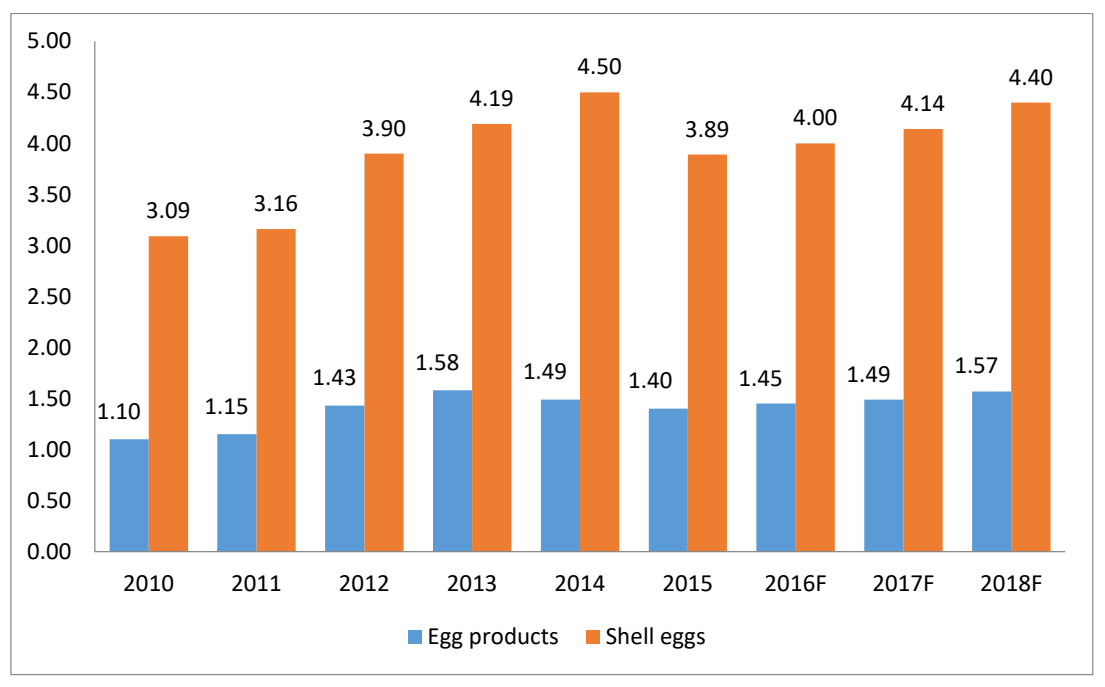

Fig. 1: World import of eggs and egg products, billion USD.

Source: Pro-Consulting. Egg market review. International Trade Centre. Available at: https://proconsulting.ua/base/analiz-rynka-ukrainy. 


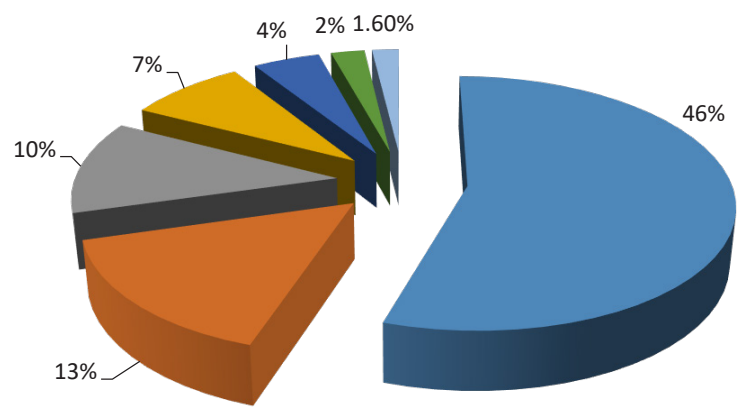

口EU, $46 \%$

MENA, $13 \%$

- Far East, 10\%

- CIS, $7 \%$

- Southen Asia, 4\%

- SSA, $2 \%$

Other, $1,6 \%$

Fig. 2: Breakdown of world imports of eggs and egg products in 2015.

Source: Pro-Consulting. Egg market review. International Trade Centre. Available at: https://proconsulting.ua/base/analiz-rynka-ukrainy.

Asian countries demonstrated the highest growth rates, the impetus related to the growth in demand for animal proteins by increasing population and the inability to meet the demand through domestic production.

However, despite globalization, egg production is traditionally national; $97 \%$ of eggs are consumed within the country of original production, and only $3 \%$ of the products are offered on the world market (International Egg Commission, 2017).

World imports of eggs and egg products (Figure 1) are characterized by stable growth during 2010-2014, as confirmed by the positive dynamics of consumption. The main reasons for the decline of egg imports (by 0.61 billion USD) and egg products (by 0.09 billion USD) in the world are simultaneous reduction in demand in EU, MENA and CIS markets in 2015. According to the International Trade Centre forecast, in 2016 imports will resume gradual growth, and in 2018 the volume of purchases in financial terms will reach the level of 2014. In 2015 geographical structure of world imports was similar to that of 2011 (Figure 2). The largest importer in the world was the EU, with a share of $46 \%$ of world imports; MENA countries occupied 13\% of total egg products imported; the Far East, 10\% (Pro-Consulting).

Detailed information on the regions is given in Table 5.

The EU market is characterized by significant domestic production in the amount of 7.4 million tons of eggs; annual per capita consumption is 221 eggs (Table 5). The fall in imports (by 16\%) was due to increased supply of domestic producers who have met the requirements of the European Council Directive 1999/74/EC. In 2015, the foreign trade balance of eggs in the EU was 1040 thousand tons. Significant import is caused by the need for egg products (55\% of world imports). 


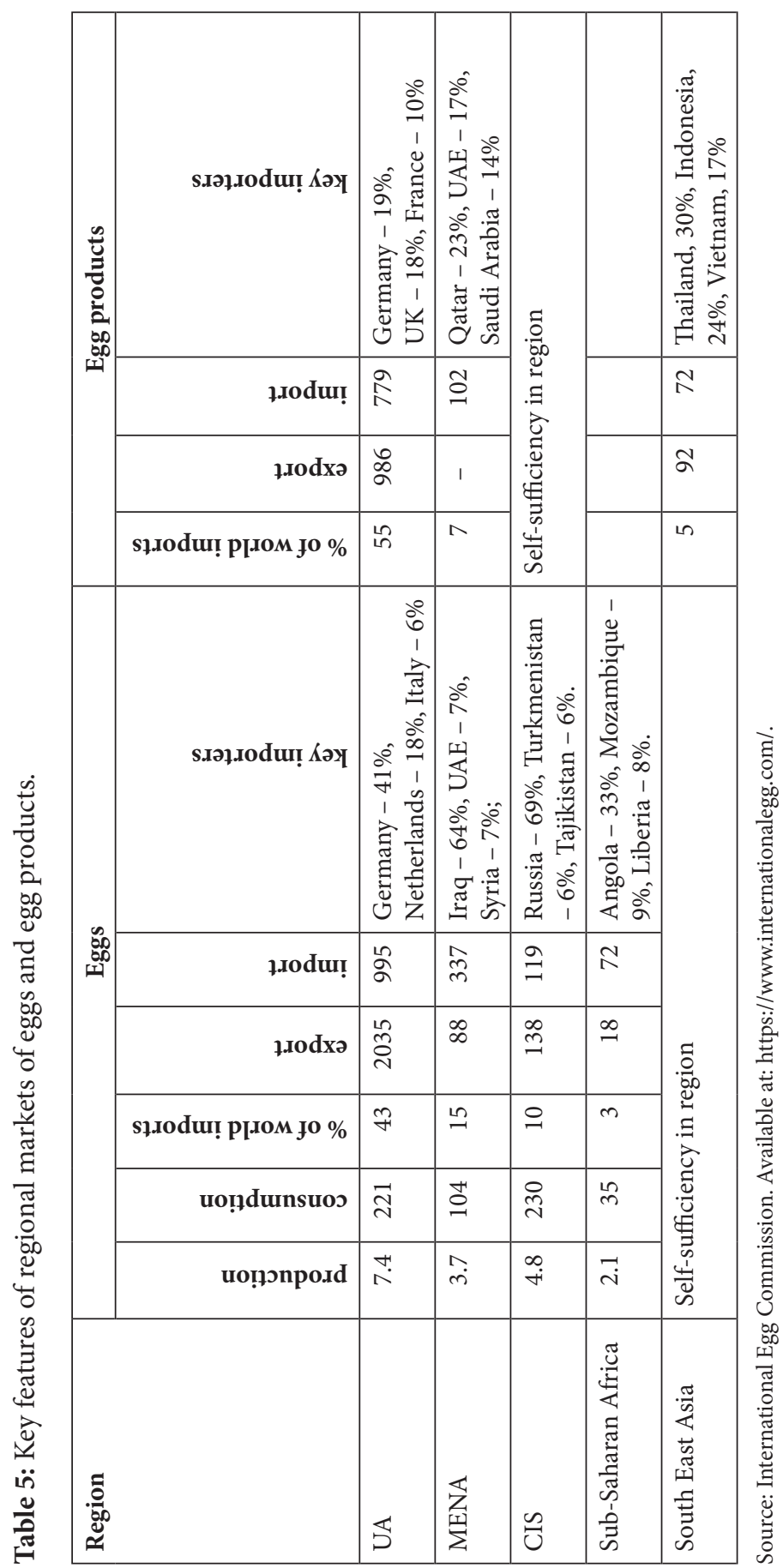


The main importers of eggs were: Germany - $41 \%$, Netherlands - $18 \%$, Italy $6 \%$; egg products: Germany - 19\%, United Kingdom - 18\%, France - 10\%.

In 2015, MENA countries were produced 3.7 million tons of eggs, and the eggs trade balance was negative ( -249 thousand tons). The region is a net importer by egg products, since there is no domestic production. MENA countries bought $15 \%$ of the world imports of eggs and $7 \%$ of egg products respectively. The market is growing and attractive; the level of its consumption is two times less in comparison with Europe - only 104 eggs per capita. The main regional importers of eggs were: Iraq - 64\%, UAE - 7\%, Syria - 7\%; egg products: Qatar - 23\%, UAE - 17\%, Saudi Arabia - 14\%.

CIS countries are able to meet their own needs within the Eurasian Union. The main regional importers of eggs were: Russia $-69 \%$, Turkmenistan $-6 \%$, Tajikistan $-6 \%$.

The countries of Sub-Saharan Africa have remained import-dependent (consumption is 35 eggs per capita), among the main regional importers of eggs were: Angola - 33\%, Mozambique - 9\%, Liberia - 8\%.

The Far East region had negative balance of 251 million USD and 18\% of world imports. The main regional importers of eggs were: Japan $-77 \%$, Taiwan $-9 \%$, South Korea $-8 \%$.

\section{The egg and egg product market of Ukraine}

Egg production in Ukraine had a weak upward trend till 2013. The period of 2014 is characterized by a decline in production by 27.5 thousand pieces or $0.1 \%$. The beginning of the antiterrorist operation and occupation of Crimea caused the loss of production capacity for the production of eggs in eastern Ukraine and the Crimean Autonomous Republic, which led to a significant decline in production. In comparison with indicators of 2014, production cuts were $14.3 \%$ (2804.4 thousand pieces); however, compared with the index of production in 2005, production of eggs increased by $28.6 \%$.

In the near future in Ukraine, there will be a tendency towards declining egg production. The trend may change if the export of eggs will show growth. Decommissioning of the operating capacity of enterprises producing eggs has caused changes in the producers' structure. Thus, in 2014 agricultural enterprises produced $64.0 \%$ of the eggs; in 2015 the share of industrial production dropped to $58.2 \%$. Reduction in industrial egg production was 2804.4 million pieces or by $14,3 \%$ (table 6 ), while households were reduced their production only by 30.4 million pieces $(0.4 \%)$.

However, over the studied period industrial egg production has increased by 3.3 times, while households increased production only by 1.2 times.

There is a concentration of production in the industry. Distributions of companies that produce eggs by capacity and production volumes in 2015 are presented in Table 7. 


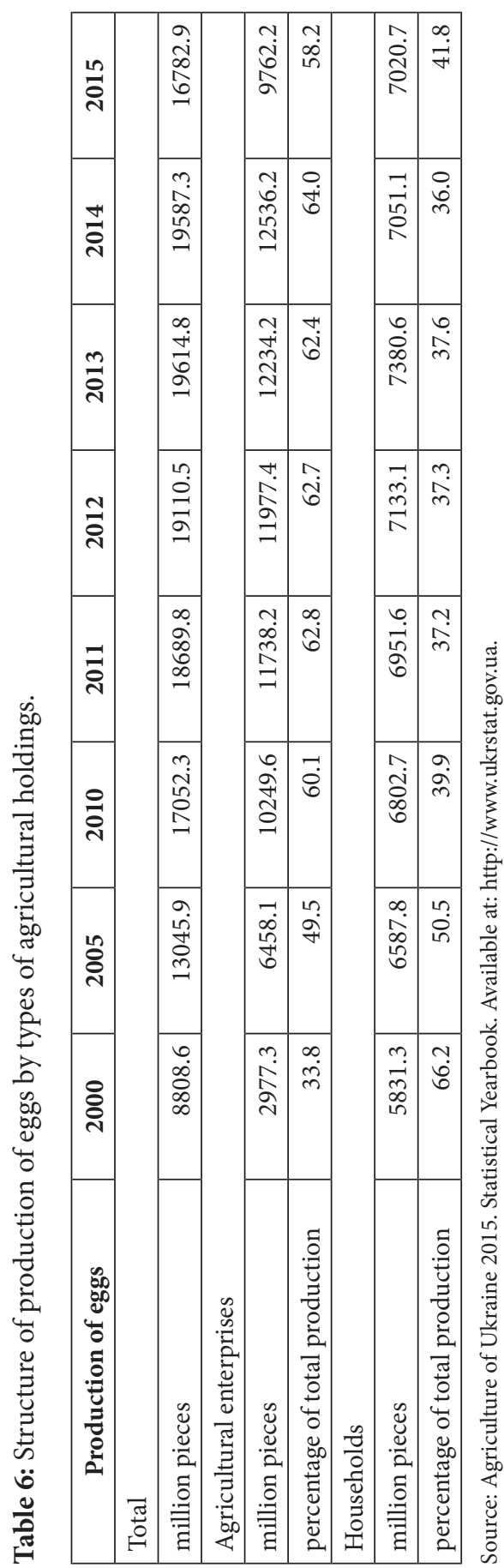


Table 7: Groupings of agricultural enterprises by production of eggs in 2015.

\begin{tabular}{|l|r|r|r|r|}
\hline & \multicolumn{2}{|c|}{ Number of enterprises } & \multicolumn{2}{c|}{ Production of eggs } \\
\cline { 2 - 5 } & units & $\begin{array}{c}\text { percentage to } \\
\text { total enterprises }\end{array}$ & million & $\begin{array}{c}\text { percentage of } \\
\text { total production }\end{array}$ \\
\hline $\begin{array}{l}\text { Enterprises producing } \\
\text { of eggs - total of which, } \\
\text { thousand pieces }\end{array}$ & 392 & 100.0 & 9762.2 & 100.0 \\
\hline no more than 10.0 & 116 & 29.6 & 0.3 & 0.0 \\
\hline $10.1-50.0$ & 56 & 14.3 & 1.4 & 0.0 \\
\hline $50.1-100.0$ & 24 & 6.1 & 1.6 & 0.0 \\
\hline $100.1-500.0$ & 50 & 12.8 & 12.6 & 0.1 \\
\hline $500.1-1000.0$ & 7 & 1.8 & 5.1 & 0.1 \\
\hline $1000.1-5000.0$ & 24 & 6.1 & 58.5 & 0.6 \\
\hline $5000.1-10000.0$ & 26 & 6.6 & 187.9 & 1.9 \\
\hline $10000.1-50000.0$ & 41 & 10.5 & 932.6 & 9.6 \\
\hline more than 50000.0 & 48 & 12.2 & 8562.2 & 87.7 \\
\hline
\end{tabular}

Source: Agriculture of Ukraine 2015. Statistical Yearbook. Available at: http://www.ukrstat.gov.ua.

Thus, 48 enterprises, which produced more than 50 thousand eggs, had a $12.2 \%$ share of all enterprises producing eggs. They produced $87.7 \%$ of the total egg production in Ukraine, while 253 other enterprises $(64.5 \%$ of total enterprises) produced only $0.2 \%$ of all eggs that were produced in Ukraine.

An important indicator for the market characteristics is the level of self-sufficiency of the country by certain products. Self-sufficiency by eggs in Ukraine was $113.9 \%$ in 2015.

The balance of egg production and consumption is shown in Table 8 . Throughout the study period, egg production has exceeded consumption. However, if in 1995 the difference was $6.4 \%$, then in 2015, it was $28.4 \%$. Thus, the increase in the volume of egg production is oriented to external markets.

Consumption of eggs per capita in Ukraine from 2000 to 2014 has risen from 166 to 310 eggs or by $86.7 \%$. The increase of prices for eggs and reduction of purchasing power in 2015 led to a significant reduction in the consumption of eggs per capita to 280 eggs.

The reduction of capacity and the decrease of purchasing power led to the reduction of capacity in the domestic market in Ukraine. If from 2000 to 2011, consumption of eggs in Ukraine has grown, in 2011-2013 it remained almost unchanged, then in 2014-2015 consumption of eggs in Ukraine declined: in 2014 by 42 thousand tons, compared with 2013 (5.2\%); in 2015 the tendency was stronger and led to decrease of 77 thousand tons.

Since 2007, foreign trade of eggs in Ukraine has been positive. The largest share in exports egg production had was in 2015 - 18.1\%. In 2014, 147 


\begin{tabular}{|c|c|c|c|c|c|c|c|c|c|c|c|}
\hline 룰 & ลे & 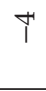 & $\exists$ & म̊ & 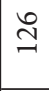 & $\begin{array}{l}0 \\
\end{array}$ & $\vec{\sim}$ & $\overrightarrow{8}$ & 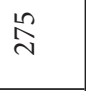 & $\stackrel{0}{r}$ & $\underset{\infty}{\infty}$ \\
\hline 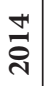 & $\vec{\Xi}$ & 0 & $n$ & $\stackrel{\infty}{\stackrel{n}{=}}$ & 多 & $\tilde{6}$ & $\hat{m}$ & $\vec{N}$ & : & No & $\begin{array}{c}0 \\
\dot{n}\end{array}$ \\
\hline$\stackrel{m}{\stackrel{\sim}{\sim}}$ & $\stackrel{m}{=}$ & 0 & in & $\stackrel{\infty}{=}$ & $\stackrel{2}{\circ}$ & $\stackrel{0}{\infty}$ & 우 & $\frac{m}{\infty}$ & ్ㅣ & $\stackrel{\infty}{i}$ & $\ddot{q}$ \\
\hline 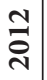 & $\underset{\exists}{\stackrel{J}{O}}$ & $n$ & $H$ & $\stackrel{\vec{\Xi}}{=}$ & $\infty$ & $\stackrel{ }{N}$ & $\hat{n}$ & $\begin{array}{l}0 \\
\infty\end{array}$ & ঐ̆ & $\stackrel{n}{n}$ & 苟 \\
\hline $\overrightarrow{\vec{d}}$ & શิ & $\leftrightarrows$ & $m$ & $\mid \begin{array}{l}\infty \\
0 \\
0 \\
0\end{array}$ & $\infty$ & $\stackrel{\mathscr{L}}{ \pm}$ & ส & $\begin{array}{l}\infty \\
\infty\end{array}$ & $\overrightarrow{\mathrm{N}}$ & $\begin{array}{l}\infty \\
\stackrel{n}{n}\end{array}$ & 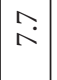 \\
\hline$\stackrel{\circ}{\stackrel{ }{2}}$ & $\begin{array}{l}0 \\
\infty \\
\infty\end{array}$ & $a$ & $n$ & $\begin{array}{c}m \\
\infty\end{array}$ & $\stackrel{2 n}{N}$ & $\stackrel{\mathscr{2}}{\underset{I}{\sim}}$ & $\stackrel{0}{-}$ & $\hat{\sigma}$ & $\stackrel{\infty}{\vec{v}}$ & $\stackrel{9}{\wedge}$ & $\begin{array}{l}0 \\
0 \\
1\end{array}$ \\
\hline ڤ્নે & $\frac{\partial}{\sigma}$ & $\simeq$ & $\wedge$ & $\vec{\sigma}$ & $\infty$ & 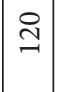 & $\exists$ & $\mathbb{N}$ & $\hat{\Omega}$ & $\begin{array}{l}0 \\
\infty \\
\infty\end{array}$ & $\begin{array}{l}0 \\
\dot{m}\end{array}$ \\
\hline 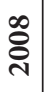 & $\tilde{\infty}$ & ㄱ. & $\wedge$ & $\begin{array}{l}\stackrel{i}{\infty} \\
\infty\end{array}$ & $\ddot{\sim}$ & $\stackrel{10}{=}$ & 10 & $\hat{\hat{\sigma}}$ & $\underset{0}{0}$ & $\hat{\infty}$ & $\widehat{\grave{v}}$ \\
\hline ટ્ণે & $\underset{\infty}{\stackrel{\sim}{\infty}}$ & $\stackrel{ }{-}$ & $m$ & $\begin{array}{l}2 \\
\infty \\
\infty\end{array}$ & 0 & 8 & $=$ & 恶 & $\stackrel{+}{-}$ & $\begin{array}{l}n \\
\ddot{n} \\
\infty\end{array}$ & $\begin{array}{l}0 \\
\dot{i}\end{array} \mid$ \\
\hline ¿્ટે & $\underset{\infty}{\tilde{D}}$ & $\stackrel{m}{m}$ & $m$ & হ & $\neg$ & 8 & $\simeq$ & $\widehat{\widehat{N}}$ & $\stackrel{\mathscr{L}}{ \pm}$ & $\underset{\infty}{\infty}$ & 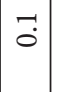 \\
\hline ஜ̊ํํ & $\stackrel{\mathscr{n}}{\wedge}$ & $\stackrel{m}{-1}$ & in & 过 & -1 & $\bar{\sigma}$ & 6 & 䒚 & $\stackrel{\circ}{\circ}$ & $\begin{array}{c}9 \\
\dot{1} \\
\infty\end{array}$ & $\overrightarrow{0}$ \\
\hline ठ્ণે & $\begin{array}{c}\infty \\
0 \\
i n\end{array}$ & $N$ & $N$ & \begin{tabular}{|l|}
$\infty$ \\
0 \\
in
\end{tabular} & 0 & i & - & $\vec{F}$ & nิ & $\hat{\alpha}$ & 0 \\
\hline そ) & 索 & $\exists$ & in & $\begin{array}{l}8 \\
8 \\
\text { in }\end{array}$ & $F$ & F & 0 & ì & $\stackrel{1 n}{n}$ & $\begin{array}{l}0 \\
\dot{a}\end{array}$ & $\stackrel{\sim}{0}$ \\
\hline 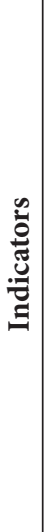 & 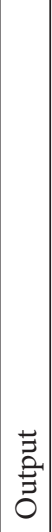 & 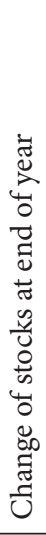 & 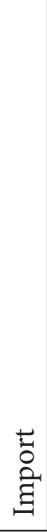 & 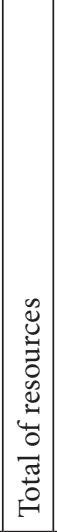 & 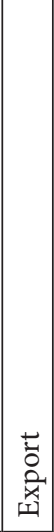 & 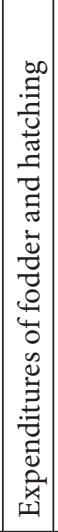 & 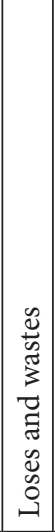 & 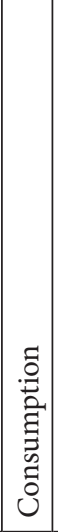 & 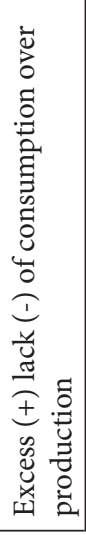 & $\begin{array}{l}\text { o̊ } \\
\tilde{0} \\
.0 \\
0 \\
0 \\
0 \\
0 \\
0 \\
0 \\
0 \\
0 \\
0 \\
0 \\
0 \\
0 \\
0 \\
0 \\
0\end{array}$ & 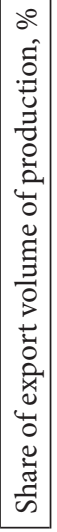 \\
\hline
\end{tabular}


thousand tons of eggs was exported from Ukraine, in 2015, it was 126 thousand tons (Figure 3).

Dynamics of prices on eggs is presented below (Figure 4).

Over the study period prices increased by 3.5 times. The biggest price increase is typical for 2014 - by 2.4 times compared with 2013 and for 2015 - by 1.7 times comparing with 2014. Such increases in 2014 and 2015 can be attributed to the rising cost of production, caused by the rising cost of energy resources.

The reduction of the domestic market was accompanied by a decrease in egg exports from Ukraine. In 2015 the pace of the decline in exports was $14.3 \%$, compared with 2014 (Figure 5).

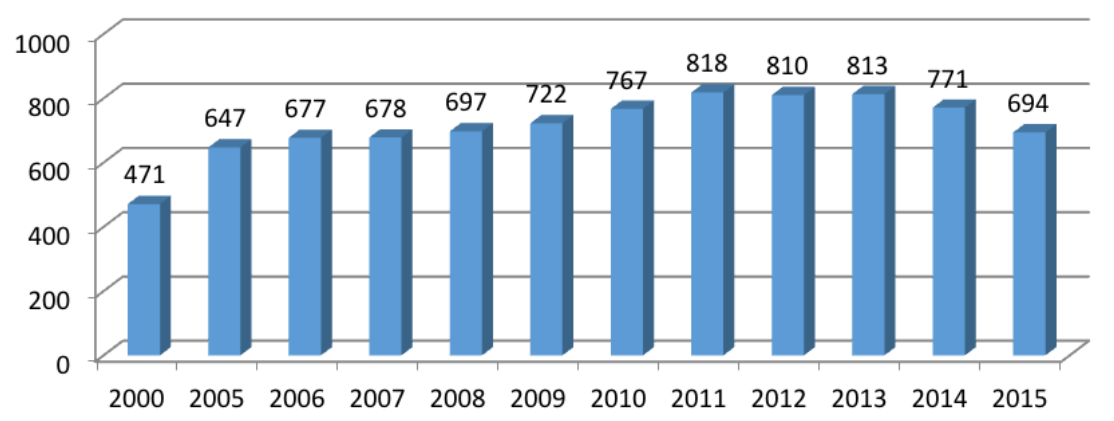

Fig. 3: Dynamics of eggs consumption in Ukraine, thousand tons.

Source: The Ministry of agrarian policy and food of Ukraine. Available at: www.minagro.gov.ua. Agriculture of Ukraine 2015. Statistical Yearbook. Available at: http://www.ukrstat.gov.ua.

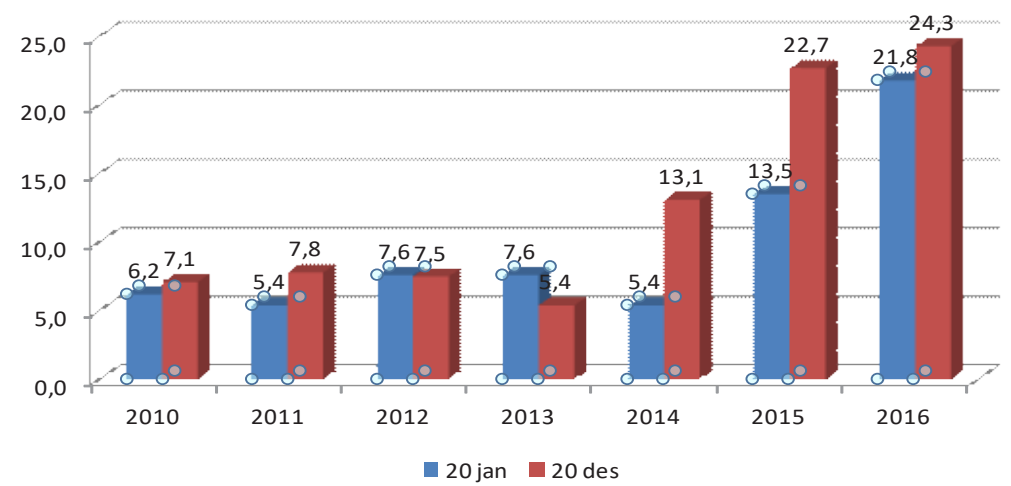

Fig. 4: Dynamics of prices on chicken eggs, UAH for 10 pieces.

Source: Agriculture of Ukraine 2015. Statistical Yearbook. Available at: http://www.ukrstat.gov.ua. 


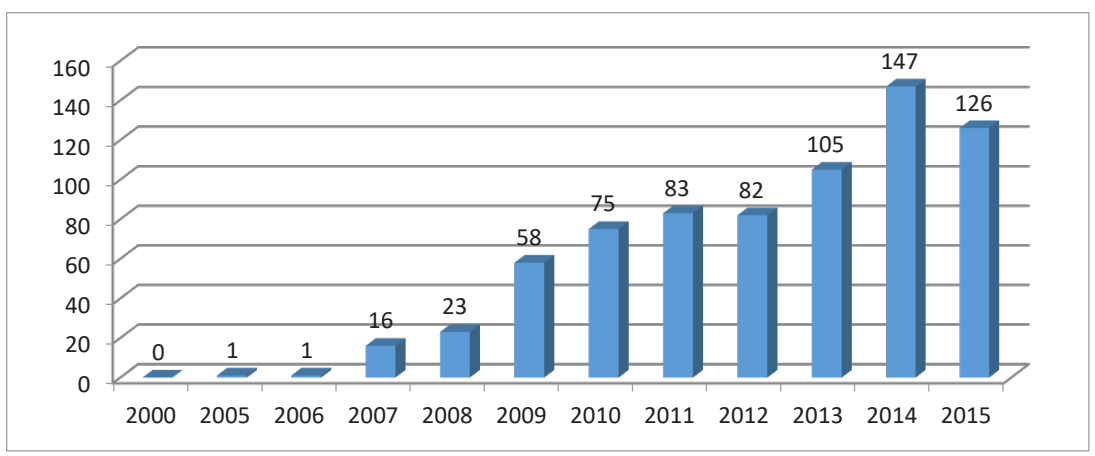

Fig. 5: Dynamics of eggs export, thousand tons.

Source: Agriculture of Ukraine 2015. Statistical Yearbook. Available at: http://www.ukrstat.gov.ua.

So, in 2015 consumption of eggs decreased by 77 thousand tons and exports decreased by 21 thousand tons.

\section{Major competitors in the egg and egg product market of Ukraine}

The egg and egg product market is sufficiently formed; powerful new players do not appear in it, and among those that are active players, there is fierce competition.

The main producers of egg products in Ukraine are AVANGARDCO (whose main specialization is the production and export of dry egg products) and Ovostar (whose main specialization is the production of a complete range of liquid and dried egg products; the export is an additional sales channel, strategically oriented to the domestic market). Due to increasing demand for higher quality and safety of food, the demand for liquid egg products is growing every year.

"Ovostar Union N.V. is a holding entity incorporated under the laws of the Netherlands consolidating companies with production assets located in Ukraine. Ovostar shares have been quoted on the Warsaw Stock Exchange since June 2011. Ovostar's mission is to produce ecologically clean and healthy food for Ukrainians. Also as Ovostar grows and gradually increases the volume of eggs produced, Ovostar develops the export markets and supplies shell eggs and egg products of consistently high quality to different international clients. Within the egg segment, Ovostar constantly focuses on meeting the demand of Ukrainian middle-class consumers" (Ovostar(a)).

With a shell egg portfolio of over 20 sub-brands, the company supplies branded eggs to the largest retail chains in Ukraine. Additionally, as a result of gradually increasing egg production, Ovostar is developing a presence on export markets. Within the egg products segment, Ovostar offers the full range 
of egg products in both liquid and dry forms. By adjusting the products to the clients' needs (while maintaining the superior quality) Ovostar achieves the loyalty of largest food-processing companies in Ukraine and outside.

Ovostar production sites "employ the most up-to-date poultry and processing equipment and progressive technological concepts in order to ensure the efficiency of production processes and superior quality of final products" (Ovostar(b)). Having initially adopted a large-scale production approach, Ovostar's vertically integrated business model spans the full production cycle, from parent flock to egg processing. In addition to core business, Ovostar maintains their own fodder production, processing of rapeseeds and grain storage in order to ensure the high quality of the poultry fodder provided to Ovostar's poultry flock. Ovostar products are compliant with international quality standards ISO 9001:2008 and ISO 22000:2005, FSSC 22000 as well as applicable national Ukrainian standards and sanitary norms. Ovostar also possess the Halal Certificate to export internationally.

The share of Ovostar Union in production of liquid egg products in Ukraine is 94\% (2014: 90\%); the share of Ovostar Union in production of dry egg products in Ukraine is 13\% (2014: 6\%); the share of Ovostar Union in industrial egg production of Ukraine is $12 \%$ (2014: $8 \%$ ).

The volume of eggs sold in 2015 grew by $18 \%$ to 862 million eggs, resulting in USD 53.2 million of total revenue (2014: USD 48.6 million). Ukraine is Ovostar's major market and Ovostar's supply of eggs on the local market remained the same year to year: 634 million eggs or $73 \%$ of Ovostar's sales volume (2014: 644 million eggs or 88\%). The growth the volume of shell eggs for sale was mainly directed for export. In 2015, the volume of eggs exported increased 2.6 times, from 89 to 229 million eggs. The export price during the first three quarters of 2015 was higher than the local price in USD terms. Ovostar's average selling price of shell eggs over the year increased by $68 \%$ to $1.374 \mathrm{UAH} /$ egg compared to $0.819 \mathrm{UAH} /$ egg in 2014.

"In 2015 Ovostar processed 347 million eggs (2014: 319 million eggs) producing 6787 tons of liquid and 1924 tons of dry egg products. The production plan of egg products was adjusted to a stronger focus on export-oriented dry egg products. In 2015 this segment generated USD 18.2 million of total revenue" (Ovostar(b)).

"The revenue from export sales over 2015 increased by 85\% to USD 21.6 million and was received mostly in USD. The Middle East is Ovostar's key export market as the region is rather close in distance via sea transportation and can offer an attractive price for eggs and egg products. As the deep and comprehensive EU-Ukraine free trade agreement was enforced, Ovostar started to export the egg products to the EU in June 2015" (Ovostar, 2015).

Under the influence of changes in foreign and domestic markets and the actions of their major competitor, the company AVANGARDCO began restructuring their businesses. 


\section{Enterprise's risks and directions of structural changes of AVANGARDCO IPL under the influence of international factors and international market}

The development of enterprises is only possible if they are ready to adapt to new consumer demands, including issues related to ecological compatibility of the production and product quality. The basic risks of AVANGARDCO have been investigated in order to identify "bottlenecks" and the prospects for overcoming them for consumers. Information about such risks and ways for overcoming them is on the company's official website and product packaging, as an element of the safety strategy of the company (www.ovostar.ua/en/).

"The risk of getting a foodborne illness from eggs is very low. In addition to food, bacteria also need moisture, a favorable temperature and time in order to multiply and increase the risk of illness. In the rare event that an egg contains bacteria, consumer can reduce the risk by proper chilling and eliminate it by proper cooking.

Over recent years, the bacterium Salmonella enteritidis ( $\mathrm{Se}$ ) has been found inside a small number of eggs. Scientists estimate that, on average across the U.S., only 1 of every 20,000 eggs might contain the bacteria. So, the likelihood that an egg might contain Se is extremely small - 0.005\% (five one-thousandths of one percent). At this rate, if you're an average consumer, you might encounter a contaminated egg once every 84 years.

Other types of microorganisms could be deposited along with dirt on the outside of an egg. So, eggshells have to be washed and sanitized to remove possible hazards.

But, like all natural organic matter, eggs can eventually spoil through the action of spoilage organisms. Although they're unpleasant, spoilage organisms don't cause foodborne illness. The bacteria Streptococcus, Staphylococcus, Micrococcus and Bacillus may be found on egg shell surfaces because all these species can tolerate dry conditions. As the egg ages, though, these bacteria decline and are replaced by spoilage bacteria, such as coliform and Flavobacterium, but the most common are several types of Pseudomonas. Pseudomonascan grow at temperatures just above refrigeration and below room temperatures and, if they're present in large numbers, may give eggs a sour or fruity odor and a blue-green coloring.

Although it is more likely for bacteria to cause spoilage during storage, mold growth can occur under very humid storage conditions or if eggs are washed in dirty water. Molds such as Penicillium, Alternaria and Rhizopus may be visible as spots on the shell and can penetrate the shell to reach the egg" (Gun, Salo, 2008; Eggs \& Food Safety).

As part of measures to minimize the loss risk of the safety of eggs and egg products through contamination or epidemics among livestock, a biological safety system has become particularly relevant, namely: 
- Location of production at a distance of more than $0.3-1.2 \mathrm{~km}$ from the residential places;

- Location of poultry plants in different regions of the country to the fastest localization of possible outbreaks of infectious diseases;

- Poultry management in closed-type industrial premises;

- Prevention of contact with wild birds;

- Usage of disinfectant barrier;

- Prevention of contact between birds of different ages through the separate retention of young birds;

- Minimize contact of employees with poultry population;

- Prohibition of poultry management in the household for employees;

- Strict control of food reserve through checking the raw materials and released products of the combine fodder factories of the company;

- Growth of their own breeding generation;

- Scheduled vaccination against Newcastle disease, Marek's disease, bronchitis and other diseases;

- Creation of own specialized laboratories in the company;

- Staff training and testing on biosafety.

The company has implemented the integrated quality management system in order to effectively manage production in the context of sustainable development. Focusing on the requests of priority export markets, the producer is guided in its activity by standards established by the International Organization for Standardization (ISO), Good Manufacturing Practice (GMP) and Good Agricultural Practices (GLOBALGAP (EUREPGAP)) on crop and livestock, namely: adherence to the international standard "Quality Management System" (ISO 9001: 2008); international standard "Food safety management systems - Requirements for any organization in the food chain" (ISO 22000: 2005); International Code of practice general principles of food hygiene (CAC / RCP 1-1969); FSSC 22000.

In the context of the quality standards the three-level security control system is applied:

- Introduced plan of HACCP;

- Developed quality auditing system by internal auditors;

- External independent bodies on certification that are involved in control.

"AVANGARDCO IPL is a socially and environmentally responsible business. The company pays special attention to the relationships with its clients, contractors, suppliers, investors and other target audiences" (Annual Report, 2015a).

Building partnerships allows for faster adjustment to the changing market environment, implementation of state-of-the-art technologies and joint creation of added value. AVANGARDCO's advantage lies in vertical integration, 
which makes it possible to effectively control every step of the production process. The company's key production facilities include hatcheries, rearing farms and laying farms. Thanks to strict control at every stage of the production process, as well as the availability of warehouses for long-term storage, the company can adjust production volumes to match demand and minimize the consequences of price fluctuation. The egg processing plant Imperovo Foods allows the company to produce high-quality egg products. The company owns six compound feed mills, which allows it to meet up to $64 \%$ of the demand for poultry feed - a key component of production costs. The company is under the process of constructing biogas plants, which will help it to resolve the environmental issue of chicken manure disposal while producing electricity and heat as well as bio fertilizers. Company products such as shell eggs and egg products are widely sold domestically, as well as exported to 42 countries.

"The investment community, creditors, government agencies, suppliers, equipment producers and NGOs also play an important role in AVANGARDCO's eco-system" (Avangardco, 2014). The desire for further development stimulates enterprise to reconsider its strategic objectives.

AVANGARDCO's mission is to promote public health by giving consumers access to affordable, healthy and safe animal proteins globally.

"AVANGARDCO IPL's focus areas are:

- Improving product quality;

- Doing business in line with global best practices;

- Combining socially and environmentally responsible business practices" (Avangardco, 2014).

Based on the research findings, some priority directions for the company development were defined, among them:

- Maintenance of the leader position in the production and supply at the domestic egg market;

- Regional expansion of the exports of eggs and dried egg products;

- Step up in exports of dried egg products for priority external markets.

Implementation of planned measures requires:

- Quality assurance through improving the ecological compatibility of the production by deepening upstream integration;

- Future steps to address biological safety issues;

- Restructuring of the product portfolio of dried egg products in accordance with the changing demand of importer;

- Obtaining of permission documentation for exports to priority markets. 
According to the growing requests of foreign markets and worsening of internal problems caused by the loss of production capacity through the annexation of the Crimea and military operations in 2015, AVANGARDCO developed and implemented a new sustainable development strategy.

The strategy envisages changes in the structure of their product portfolio, which will be formed according to customer demands. This is necessary because of the imbalance in the structure of the commodity groups of dried egg products.

World imports of dried egg products include: yolk powder - 42\%; albumen $39 \%$; dried egg yolk - 19\%. Demand for different groups are formed according to the purpose of further usage, and as it is known, egg products are the subject of industrial producers' attention.

Seeking to meet the growing demand of importers of albumen led to significant stock forming of dried yolk powder. At the same time, consumption of yolk in the domestic market did not compensate for the commodity surplus of this product. So, AVANGARDCO moved towards the formation of a product portfolio strictly according to the order of products in accordance with the specifications of the customer with the aim of avoiding overproduction of some product groups and maintaining profitability.

Adherence to high quality standards is ensured by deepening upstream integration based on environmental orientation. The company underwent certification. The plant is fully equipped with production lines SANOVO (Denmark) and is certified according to the standards FSSC 22000, ISO 22000: 2005 and ISO 9001: 2008. In 2014 "Imperovo Foods" received official permission for exports of egg products to the European Union, as well as a certificate on kosher products (Avangardco, 2015).

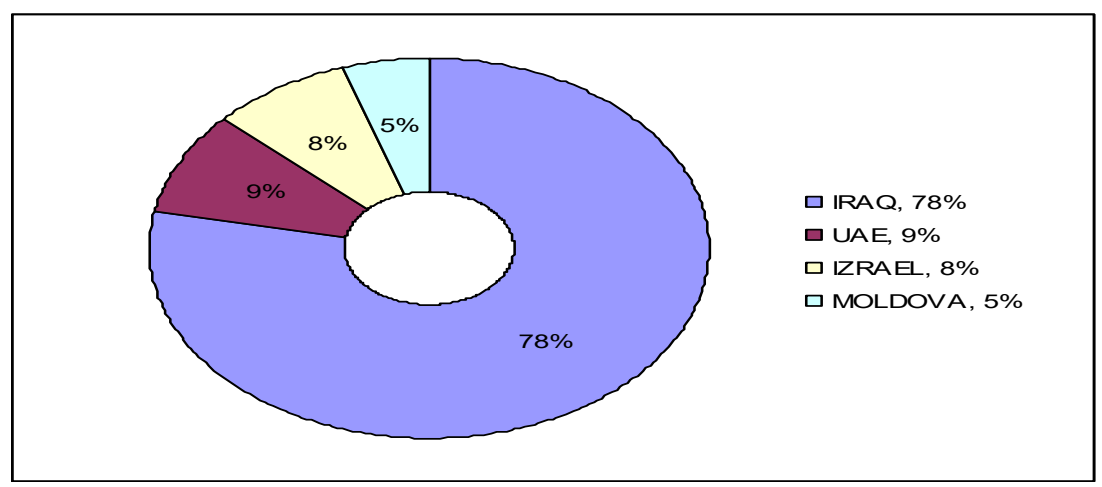

Fig. 6: AVANGARDCO top egg export markets, 2015, \% of revenue.

Source: Avangardco, 2015. http://avangardco.ua/fileadmin/files/INVESTOR_RELATIONS/ Avangardco_IPL_Annual_Report_2015_final.pdf. 
In order to diversify the regional structure of exports, AVANGARDCO has found some prospects in boosting the egg and egg product supply from Ukrainian to foreign markets, as well as researching the special demands of priority markets.

The most attractive export markets are the European Union and countries of MENA, the market of Judaic countries. In order to ensure compliance with the requirements of foreign markets on ecological compatibility of the production and quality of egg product, the company got the status of authorized exporter to the EU, and was certified halal and kosher.

The most rapidly growing market importer was the MENA region till 2015. It consists of countries of North Africa, the Middle East, the Gulf States and Turkey. Among key characteristics of the market, there are rapid population growth, increasing middle class; pent-up demand as a result of low self-sufficiency that is connected with difficulties in setting up of local production due to adverse climatic conditions. Among the threats, there are economic instability caused by military actions (Syria, Iraq). Today the MENA region has dependence on imports of eggs; it is a net importer in the segment of egg products (Figure 6).

There is further re-orientation of the market towards increasing egg product purchases and the gradual withdrawal of import eggs.

Because the popular majority of MENA countries are Muslims, permission for export of products must be confirmed by certified halal. The certificate confirms that the eggs obtained from hens that were fed without meat and bone meal. Compliance with the halal food standards applies strict control over

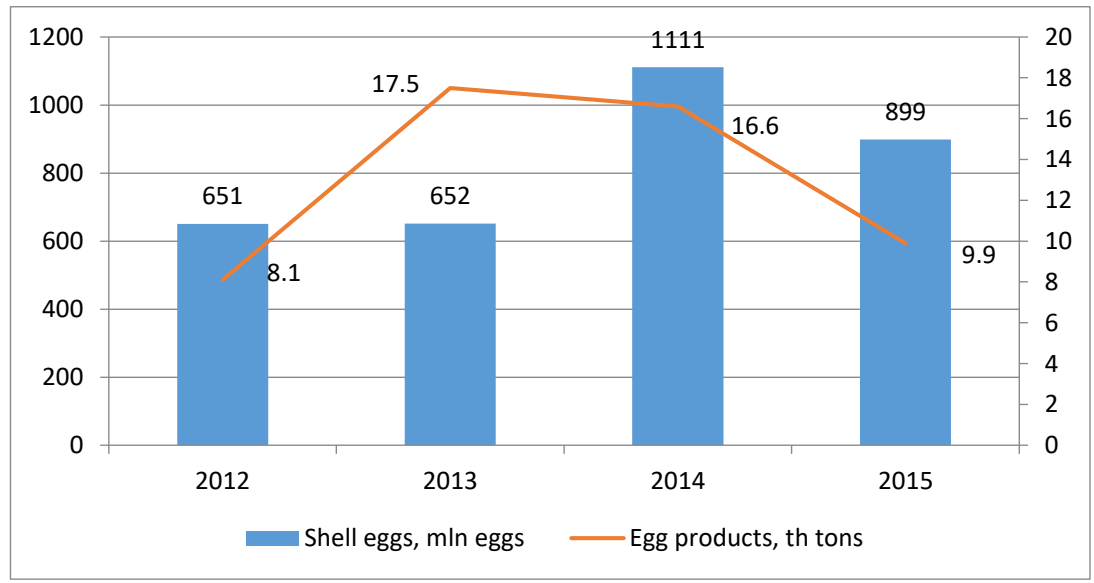

Fig. 7: Export of shell eggs and egg products from Ukraine.

Source: Avangardco, 2015. http://avangardco.ua/fileadmin/files/INVESTOR_RELATIONS/ Avangardco_IPL_Annual_Report_2015_final.pdf. 
chickens' nutrition. The company has confirmed the quality of halal production by the halal certification, and they received automatic access to the markets of all Muslim countries in the world. However, a significant symptom of missing the most profitable market is the import reduction of the region by $18 \%$, in particular by $33 \%$ in Iraq in 2015. It is because of further escalation of military conflicts.

Also, in order to expand export deliveries to the markets of kosher product's consumers AVANGARDCO has been certified as kosher, which is evidence of "purity" of the product, abidance by the terms of feeding and keeping chickens.

The growing interest of Avangardco in the market of the EU is explained:

- Geographical availability;

- Need for re-orientation of egg product deliveries because of sanctions to the Russian Federation (before - $2 \%$ of exports), decrease in demand of MENA countries (18\%);

- Significant profitability (less costs than those of European producers through upstream integration, the devaluation of the hryvnia);

- Significant difference in price of export and realization in the Ukrainian market.

Avangardco IPL successfully completed environmental restructuring in accordance with the requirements of European legislation in 2012. In 2014 the company received the status of an authorized exporter, "Imperovo Foods Ltd" (Ukraine Eggs and egg products Approval number 09-15-36 EGG 25/07/2014).

Features of the EU market for exports:

- of eggs - the narrowness of the quota for duty-free supply and the complexity of its receipt. At delivery over the quota, a company is unable to compete with the local producers.

- of egg products - pent-up demand, price competitiveness even without duty exemption.

The priority country for egg product deliveries is Denmark, which bought $38 \%$ of exports in 2015.

A step up in exports to the EU will be promoted because according to the Association Agreement between the EU and Ukraine, a duty-free quota for the supply of egg products and albumen was received in the amount of 1500 tons per year in conversion to eggs in their eggshells, followed by a gradual increase in quotas over five years up to 3000 tons per year (in conversion to eggs in eggshells) and 3000 tons per year in net weight.

Thus, the domestic producer AVANGARDCO is a powerful exporter whose products are represented in the markets of 42 countries and the company consistently provides eggs and egg products at the national market. 
Table 9: Regional structure of the eggs and egg products' exports by Avangardco, 2014-2015.

\begin{tabular}{|c|c|c|}
\hline Commodity & 2014 & 2015 \\
\hline Eggs & $\begin{array}{l}\text { Iraq - } 69.1 \% \\
\text { Liberia }-25.6 \% \\
\text { Moldova }-4.8 \% \\
\text { Turkey }-0.3 \% \\
\text { UAE - } 0.2 \%\end{array}$ & $\begin{array}{l}\text { Iraq - 78\%, } \\
\text { UAE - 9\%, } \\
\text { Israel - 8\%, } \\
\text { Moldova - } 5 \%\end{array}$ \\
\hline Egg products & $\begin{array}{l}\text { Jordan - } 24 \% \\
\text { Taiwan - } 19 \% \\
\text { UAE - } 18 \% \\
\text { Indonesia - } 14 \% \\
\text { Turkey - } 7 \% \\
\text { Other - } 18 \%\end{array}$ & $\begin{array}{l}\text { Denmark - 38\% } \\
\text { Taiwan - } 17 \% \\
\text { Indonesia - } 14 \% \\
\text { Thailand - } 8 \% \\
\text { Pakistan }-7 \% \\
\text { Other - } 16 \%\end{array}$ \\
\hline
\end{tabular}

Source: Avangardco, 2015. http://avangardco.ua/fileadmin/files/INVESTOR_RELATIONS/ Avangardco_IPL_Annual_Report_2015_final.pdf.

In 2015 Ukrainian exports of eggs fell by 19\% (in physical terms) [ According to "Agriculture of Ukraine 2015. Statistical Yearbook." Available at: http:// www.ukrstat.gov.ua], AVANGARDCO retained the share of exports, at $48 \%$ (Table 9).

Among the importers of eggs that successfully work with AVANGARDCO there are: Iraq - 78\%, UAE - 9\%, Israel - 8\%, Moldova - 5\%; importers of egg products: Denmark - 38\%, Taiwan - 17\%, Indonesia - 14\%, Thailand $-8 \%$, Pakistan $-7 \%$.

The MENA region has remained the most profitable for the company because it consumes more than $90 \%$ of Ukrainian egg exports.

\section{Conclusions}

The international market of eggs belongs to growing markets, due to the fact that eggs are one of the cheapest products.

The egg market is very vulnerable due to the significant influence of external environmental factors.

The traditional world leader in production of eggs, since 1990, has been China; the United States occupied the second place and India and Japan are competing for the third place. In 2010-2013 Ukraine has ranked ninth in the production of eggs. Egg production is traditionally national; 97\% of eggs are consumed within the country of original production, and only $3 \%$ of the products are offered on the world market. 
The EU market is characterized by significant domestic production in the amount of 7.4 million tons of eggs; annual per capita consumption is 221 eggs. In 2015, the foreign trade balance of eggs in the EU was 1040 thousand tons. Significant import is caused by the need for egg products (55\% of world imports).

Egg production in Ukraine had a weak upward trend till 2013. The period of 2014 is characterized by a decline in production by 27.5 thousand pieces or $0.1 \%$. The beginning of the antiterrorist operation and occupation of Crimea led to a significant decline in production. In comparison with indicators of 2014, production cuts were $14.3 \%$ (2804.4 thousand pieces); however, compared with the index of production in 2005, production of eggs increased by $28.6 \%$.

In the near future in Ukraine, there will be a tendency towards declining egg production. The trend may change if the export of eggs will show growth.

Agricultural enterprises produced $64.0 \%$ of the eggs in 2014. In 2015, the share of industrial production dropped to $58.2 \%$. Reduction in industrial egg production was 2804.4 million pieces or by $14.3 \%$, while households were reduced their production only by 30.4 million pieces $(0.4 \%)$.

48 enterprises, which produced more than 50 thousand eggs, had a $12.2 \%$ share of all enterprises producing eggs. They produced $87.7 \%$ of the total egg production in Ukraine, while 253 other enterprises (64.5\% of total enterprises) produced only $0.2 \%$ of all eggs that were produced in Ukraine.

Consumption of eggs per capita in Ukraine from 2000 to 2014 has risen from 166 to 310 eggs or by $86.7 \%$. The increase of prices for eggs and reduction of purchasing power in 2015 led to a significant reduction in the consumption of eggs per capita to 280 eggs.

Over the study period prices of eggs increased by 3.5 times. The biggest price increase is typical for 2014 - by 2.4 times compared with 2013 and for 2015 by 1.7 times comparing with 2014. Such increases in 2014 and 2015 can be attributed to the rising cost of production, caused by the rising cost of energy resources.

The main producers of egg products in Ukraine are AVANGARDCO (whose main specialization is the production and export of dry egg products) and Ovostar (whose main specialization is the production of a complete range of liquid and dried egg products; the export is an additional sales channel, strategically oriented to the domestic market). Due to increasing demand for higher quality and safety of food, the demand for liquid egg products is growing every year.

The company that aims to be the leader in the Ukrainian egg and egg product market and strengthen its competitive position in foreign markets has to adapt to changing conditions, in both national and global markets.

A complex set of external and internal factors has influenced AVANGARDCO's activity in the Ukrainian market; moreover, negative domestic economy factors led them to strengthen their positions in international markets, namely: 
- political and legal factors, among which are: military actions and the annexation of Crimea (loss of capacity); lack of legislative stability and a high degree of government influence on the economy, particularly changes in currency legislation in terms of exchange controls for foreign economic activity of enterprises (adjustment of period inflow of foreign currency, part of the obligatory sale of foreign exchange earnings, complications of purchase foreign currency for import transactions), revision of tax laws (VAT refunds, functioning of special regimes).

- economic factors, among which are: decrease in demand in the Ukrainian market; devaluation processes because the currency is a favourable factor for the development of an exporter, less than inflation, adjusting domestic demand; lack of access to credit resources; an oligopoly in the egg market and a duopoly in the egg product market.

Analyzing the factors of international environment, it is appropriate to note that the greatest impact on the aspiration to implement the new strategy for AVANGARDCO to enhance their competitive position as a producer and exporter were made: the fall in food prices in the world and the reduction in world imports of eggs and dry egg products.

An integral part of the strategic reorientation implementation, aimed to expand presence at foreign markets, was the environmental component (biosafety, improving the conditions of keeping chickens). The bases for its implementation were the following factors of international environment included increasing requirements for quality and environmental friendliness of products in the EU (mandatory for obtaining status of Permanent Exporter) and the MENA countries' market requirements regarding product conformity to the Muslim religion (obtaining Halal Certificate) and the Jewish faith (Kosher Certificate).

Among the favourable international factors in the EU market (ranged from most to least influential) were:

- Signing of an agreement with EU;

- Open borders of the European market by providing quotas for a duty-free supply of eggs and egg products;

- Stability law (legal security of supplier through compliance with the contract);

- Significant difference in price between the EU and Ukraine;

- High demand; and

- Progressive population that reflected an interest in ecological/organic/ environmental-friendly food, the aspiration to a healthy lifestyle.

Among the favorable international factors at market of MENA countries are: 
- Growing population;

- Increasing middle class;

- Lack of domestic production of eggs and egg products; and

- Transparency of requirements for quality and safety products.

However, despite the substantial decline in imports of egg products, especially by Iraq, it is worth noting that among threats to further cooperation, the following factors (ranged from most to least influential) are included:

- Threat of deepening military conflict;

- International activities of terrorist organizations;

- Decrease in demand for products through mass migration from some countries;

- Reduction in prices for egg products; and eggs;

- Risks in foreign trade agreements implementation due to the instability of the political situation.

The level of influence of each determinant on company activity under its restructuring processes is demonstrated in Table 10.

Table 10: Levels of influence of determinants on the company's activity under its restructuring processes.

\begin{tabular}{|l|l|r|}
\hline \multicolumn{1}{|c|}{ Determinant } & Points \\
\hline Economic factors & 9 \\
\hline 1 & Interest rates & 8 \\
\hline 2 & Inflation rate & 9 \\
\hline 3 & The national currency exchange rate & 2 \\
\hline 4 & The unemployment rate & 3 \\
\hline 5 & The degree of savings and debt society & 3 \\
\hline 6 & Salaries & 8 \\
\hline 7 & The availability of credits for businesses and households & 9 \\
\hline 8 & Competition in core market & 6 \\
\hline 9 & Consumer confidence & 10 \\
\hline 10 & Access to capital & 10 \\
\hline 11 & Level of taxes change & 10 \\
\hline Political and legal factors & 10 \\
\hline 12 & Stability of legislation in the country & \\
\hline 13 & The degree of intervention of the government in the economy & \\
\hline
\end{tabular}




\begin{tabular}{|c|c|c|}
\hline 14 & The national political situation & 10 \\
\hline 15 & International trade regulations and legislative restrictions & 10 \\
\hline 16 & Consumer protection law & 5 \\
\hline 17 & Labour Law & 4 \\
\hline \multicolumn{3}{|c|}{ Political and legal aspects of the international market } \\
\hline 18 & Preventing of monopolistic tendencies and unfair competition & 2 \\
\hline 19 & Increasing of entry barriers for particular activities & 2 \\
\hline 20 & Ensuring the safety of the products & 10 \\
\hline 21 & Protecting the interests of weaker market participants & 3 \\
\hline 22 & Protection of the environment. & 7 \\
\hline 23 & The global political situation & 10 \\
\hline \multicolumn{3}{|c|}{$\begin{array}{l}\text { Socio-cultural factors in both national and international sense, and the relationships } \\
\text { between them }\end{array}$} \\
\hline 24 & $\begin{array}{l}\text { The civilizational progress (lifestyle and its changes, the knowledge } \\
\text { of the living standards in other countries) }\end{array}$ & 7 \\
\hline 25 & Society mobility & 6 \\
\hline 26 & The level of education & 1 \\
\hline 27 & Local community initiatives & 1 \\
\hline 28 & The awareness of civil and consumer rights & 2 \\
\hline 29 & Religion & 10 \\
\hline \multicolumn{3}{|c|}{ The technological factors } \\
\hline 30 & State or company expenditures for Research and Development & 8 \\
\hline 31 & The speed of up-to-date technology transfer & 7 \\
\hline 32 & The level of transport development & 9 \\
\hline 33 & The frequency of the new products' appearance & 10 \\
\hline 34 & $\begin{array}{l}\text { New tendencies of changes in realisation of business challenges, } \\
\text { mobile technologies }\end{array}$ & 9 \\
\hline 35 & The level of technological modernity industry & 8 \\
\hline 36 & New inventions and development of science & 8 \\
\hline 37 & Opportunities and the knowledge transfer and technology costs & 7 \\
\hline 38 & The life cycle of products and the speed of technological changes & 6 \\
\hline \multicolumn{3}{|c|}{ International factors } \\
\hline 39 & The economic situation on the world & 8 \\
\hline 40 & The opening of the borders & 10 \\
\hline 41 & $\begin{array}{l}\text { The stability of political, economic and tax systems in the countries } \\
\text { that are the area of the industry interest }\end{array}$ & 10 \\
\hline
\end{tabular}




\begin{tabular}{|l|l|r|}
\hline 42 & The international agreements and regulations & 10 \\
\hline 43 & The probability of an international armed conflict & 10 \\
\hline 44 & International activity of terrorist organizations & 10 \\
\hline Ecological aspects & 1 \\
\hline 45 & $\begin{array}{l}\text { The deliberate use of air conditioners (switch off during airing } \\
\text { rooms, no use after working hours) }\end{array}$ & 4 \\
\hline 46 & Heating of water and space by using solar energy & 8 \\
\hline 47 & Switched off lights when they are not needed & 8 \\
\hline 48 & $\begin{array}{l}\text { Unused administrative units are disconnect from the electricity } \\
\text { network }\end{array}$ & $\begin{array}{l}\text { Permanent monitoring of water consumption (e.g. control of leaking } \\
\text { taps) }\end{array}$ \\
\hline 50 & Trainings of personnel in effective waste management & 4 \\
\hline 51 & $\begin{array}{l}\text { Signed contracts with suppliers to reduce the amount of unnecessary } \\
\text { packaging }\end{array}$ & 10 \\
\hline 52 & Ecological innovations & $\begin{array}{l}\text { Encouraging environmental awareness of employees and business' } \\
\text { stakeholders }\end{array}$ \\
\hline 53 &
\end{tabular}

Source: results of investigation „Management of enterprises in terms of ensuring food security” that were held by the authors in National University of Food Technologies in terms of Scientific and Research Work financed by Ukrainian Goverment (project ID: 0112U004638). Answers provided on a scale from 1 (factor almost wasn't influenced on proecological restructuring) to 10 (factor was high influenced on proecological restructuring).

Expert assessment led to the following conclusions. The role of environmental factors (economic, political and legal, socio-cultural, technological) remains the leading one. The determinants received the highest assessment of experts such as: access to capital; level of taxes change; stability of legislation in the country; the degree of intervention of the government in the economy; the national political situation; international trade regulations and legislative restrictions; ensuring the safety of the products; the global political situation; the frequency of the new products' appearance. These determinants form the highest level of efficiency in carrying out pro-ecological restructuring - 10 points.

The lowest score (1-2 points) received environmental factors such as: the unemployment rate; preventing of monopolistic tendencies and unfair competition; Increasing of entry barriers for particular activities; the level of education; local community initiatives; the awareness of civil and consumer rights; the deliberate use of air conditioners. These determinants have little effect on the company's activity under its restructuring processes. 
The study of the level of influence of individual determinants on the company's activities in the process of environmental restructuring revealed the following trends:

- the highest score among the environmental determinants were: training of personnel in the effective waste management (10 points); ecological innovations implemented by companies (10 points); encouraging environmental awareness of employees and business stakeholders (10 points);

- switched off lights when they are not needed (8 points); continuous monitoring of water consumption (e.g. control of leaking taps) (8 points); unused administrative unit are disconnect from the electricity network (6 points).

Significantly modest assessments have been made regarding unnecessary packaging ( 4 points) associated with the specifics of the analyzed product and the lack of reuse of packaging in the supply of eggs and egg products, especially on external markets. The question of use in the practical activity of Ukrainian producers of solar energy products (4 points) becomes of particular urgency; however, it is appropriate to emphasize the prospects rather than the possibilities of realization today.

Effective pro-ecological restructuring of Ukrainian enterprises is possible through providing the combined components, such as:

- an intellectual component through acquiring environmental knowledge;

- a value component through the formation of ecological consciousness;

- a legal component due to the increase of legal awareness about normative acts on ecology of Ukraine and counterpart countries; including the introduction of amendments to the legislation, namely the definition of investment priorities, along with economic and social effects, environmental impact on investment activities;

- a security component through the formation and implementation of environmental safety requirements at the micro-macro level;

- a practical component as an activity through acquiring theoretical knowledge and implementing practical skills in environmental restructuring.

Enterprises will be interested in implementing the strategy of pro-ecological restructuring only if the state establishes strict requirements for the environmental component of the production and sale of products.

At the same time, enterprises should concentrate their efforts to train personnel on effective waste management issues; implementation of environmental innovations that are implemented by companies; environmental awareness of employees and stakeholders; implementation of practices of saving material resources (electricity, water, materials). The implementation of the strategy of proecological restructuring as a component of the corporate strategy will lead to the sustainable development of enterprises and the economy of the country. 


\section{References}

Agriculture of Ukraine (2015). Statistical Yearbook. Available at: http://www. ukrstat.gov.ua

AVANGARDCO IPL. Available at: http://www.avangardco.ua/en/

Avangardco (2014), Annual Report (2014). Available at: http://avangardco.ua/ fileadmin/user_upload/AVGR_Annual_report_2014.pdf

Avangardco (2015), Annual Report 2015. Available at: http://avangardco.ua/ fileadmin/files/INVESTOR_RELATIONS/Avangardco_IPL_Annual_ Report_2015_final.pdf

Davies, J. (2018), Eggs' role in ending protein poverty Available at: https:// www.poultryworld.net/Eggs/Articles/2018/5/Eggs-role-in-ending-proteinpoverty-283827E/

Eggs \& Food Safety. Available at: https://www.incredibleegg.org/egg-nutrition/ egg-safety/

Gun Wirtanen, Satu Salo, (2008). Risk Assessment of Microbial Problems and Preventive Actions in Food Industry. 2-nd Open Seminar arranged by SAFOODNET - Food Safety and Hygiene Networking within New Member States and Associated Candidate Countries. Istanbul, Turkey, 22-23 Oct. 2007 Available at: https://www.vtt.fi/inf/pdf/symposiums/2008/S251.pdf

International Egg Commission. Available at: https://www.internationalegg.com/ International Egg Commission (2017), Annual Report (2017). Available at: https://www.internationalegg.com/new-report-on-the-dynamics-andpatterns-of-the-egg-industry-in-apec-member-countries/

Ovostar. Available at: http://www.ovostar.ua/en/

Ovostar (2015), Annual Report 2015. (Available at: http://www.ovostar.ua/ data/file/financial_reports/ovostar_union_nv_annual_report_2015.pdf

Ovostar(a). Available at: www.ovostar.ua/ru/ipo/general_information/

Ovostar(b). Available at: https://mfa.gov.ua/.../sites/.../WEB_Katalog_Ovostar_ 2015.p.

Pro-Consulting. Egg market review. International Trade Centre. Available at: https://pro-consulting.ua/base/analiz-rynka-ukrainy

State Statistics Service of Ukraine. Available at: http://www.ukrstat.gov.ua The Ministry of agrarian policy and food of Ukraine. Available at: www.minagro.gov.ua

World Egg Organization. Available at: http://www.internationalegg.com

World leaders in egg production. Poultry and Poultry products (2013) Vol.2 